\title{
Urban Design and Walkability: Lessons Learnt from Iranian Traditional Cities
}

\author{
Elmira Jamei ${ }^{1} \mathbb{D}$, Khatereh Ahmadi ${ }^{2, *}$, Hing Wah Chau ${ }^{1}$ (D), Mehdi Seyedmahmoudian ${ }^{3}$, Ben Horan ${ }^{4}$ (D) \\ and Alex Stojcevski ${ }^{3}$
}

1 College of Engineering and Science, Victoria University, Melbourne, VIC 3011, Australia; Elmira.Jamei@vu.edu.au (E.J.); Hing-Wah.Chau@vu.edu.au (H.W.C.)

2 Department of Architecture, University of Mohaghegh Ardabili, Ardabil 5619911367, Iran

3 School of Software \& Electrical Engineering, Swinburne University of Technology, Melbourne, VIC 3122, Australia; mseyedmahmoudian@swin.edu.au (M.S.); astojcevski@swin.edu.au (A.S.)

4 School of Engineering, Deakin University, Geelong, VIC 3216, Australia; ben.horan@deakin.edu.au

* Correspondence: ahmadi_khatereh@yahoo.com

check for updates

Citation: Jamei, E.; Ahmadi, K.; Chau, H.W.; Seyedmahmoudian, M.; Horan, B.; Stojcevski, A. Urban Design and Walkability: Lessons Learnt from Iranian Traditional Cities. Sustainability 2021, 13, 5731. https://doi.org/10.3390/su13105731

Academic Editor: Francesca Poggi

Received: 20 April 2021

Accepted: 13 May 2021

Published: 20 May 2021

Publisher's Note: MDPI stays neutral with regard to jurisdictional claims in published maps and institutional affiliations.

Copyright: (c) 2021 by the authors. Licensee MDPI, Basel, Switzerland. This article is an open access article distributed under the terms and conditions of the Creative Commons Attribution (CC BY) license (https:// creativecommons.org/licenses/by/ $4.0 /)$.

\begin{abstract}
Physical activity is connected to public health in many ways, and walking is its most popular form. Modern planning models have been applied to cities to manage rapid urban expansions. However, this practice has led to low level of walkability and strong car-dependency in today's cities. Hence, this study aims to provide a review of the most promising urban design parameters affecting walkability, using Frank Lawrence's theory of "Objectively Measured Urban Form" (density, connectivity and accessibility, and mixed-use development) as the basis of discussion. The second part of this paper takes a case study approach, through discussing the main design elements of traditional Iranian cities (mosques, bazaars, residential quarters, and alleyways) and analyses their impacts on promoting walkability. This study concludes that incorporating inherent values of traditional urban design elements will complement modern planning and design practices.
\end{abstract}

Keywords: walkability; traditional cities; urban design; walkable cities

\section{Introduction}

Walkability is defined as "the extent to which the built environment supports and encourages walking through providing safety, and high level of accessibility and connectivity to destinations, and visual interest within a reasonable span of time" [1]. Walking is the oldest form of human movement and the most common type of physical activity that significantly reduces the number of obesity rates in today's highly consumable societies [2]

The benefits of walking have been well documented in the literature. Scholars have indicated that walking not only leads to a higher level of physical activity and healthier lifestyle but also contributes to a reduced level of greenhouse gas emissions and therefore improved environmental sustainability [3]. Additionally, walking benefits the families with a low socio-economic background who are highly reliant on walking to reach their destinations and thereby improves social equity and sustainability. Bornet used geocoded travel diary data to quantify the health benefits of increased walkability rate caused by thoughtful urban design attributes and parameters [4]. Moreover, the potential greenhouse gas emission and carbon reduction by enhancing walkability and use of public transportation in cities were assessed through surveys, statistics and collisions databases [5]. The results showed that increasing the walkability and means of public transportation will be associated with a significant reduction in the number of deaths caused by ischemic heart disease.

Another important outcome of increased walking rate in cities is economic growth. The Health Economic Assessment Tool was used in [6] to assess the health benefit and economic growth of urban policies that encourage walking in the built environment. They 
found that human-orientated urban policies led to more walkable urban spaces and higher economic benefits.

The importance of neighbourhood design in promoting physical activity and improving public health has been well established in the literature [7-11]. However, rapid population growth, urban sprawl and de-centralisation of cities, particularly after World War II, have led to a transformation that puts cars as the basis of the design and significantly drops the walkability rate in cities. Insufficient walking in our daily lives has been reported to be more harmful than smoking [12].

Creating walkable neighbourhoods and healthy communities has been the focus of many studies in recent years [13-16]. Built environment and specifically urban design principles have emerged as a high priority for promoting walkability $[17,18]$. However, identifying the connection between urban design and walkability requires a good level of understanding of the concepts and main components that shape urban form (e.g., public spaces, streets).

Currently, the scope of the majority of studies on investigating the role of urban design in promoting walkability has been focused on contemporary built environment where a lower level of walkability has been reported $[2,19,20]$. However, studies highlighting the lessons that can be learned from old-traditional cities in relation to their public spaces design, urban morphology and inherent walkable neighbourhoods are limited. Therefore, this study aims to review the existing literature on walkability and urban design qualities that make a city walkable. Frank Lawrence's theory of 'Objectively Measured Urban Form' [21] and its three components (1-density, 2-connectivity and accessibility and 3-mixed-use development) were used as the basis of the discussions to explain the connection amongst urban form, public spaces and walkability.

In the second section of the paper, we identify the unique public spaces and urban forms in traditional Iranian cities and investigate how they contribute to walkable communities. We mainly focus on the traditional cities located in central parts of Iran, where the climatic conditions are hot and dry. The research methods include desktop review, case study and analysis of historical photos taken from public spaces, including old city plans. Frank Lawrence's theory of 'Objectively Measured Urban Form' [21] was deployed to discuss how unique urban design and public space elements (e.g., mosques, bazaars, baths [hammams], public squares [maidans], schools [madrasah] and neighbourhood [mahalleh]) in Iranian traditional cities result in a higher level of walkability.

\section{Literature Review}

\subsection{Design of Public Space and Walkability}

The design and quality of public spaces have a great influence on walkability. Studies showed that the quality of public spaces is more important than their numbers or sizes in promoting walkability $[22,23]$. High-quality public spaces were identified as the most important contributing factor in the social life of people and, therefore, in increasing the walkability rate in the neighbourhoods. The use, access, frequency of use by people and the strategic location of each public space in a neighbourhood affects the quality and attractiveness of public spaces, and people's motivation to walk.

Various factors in the design of public spaces can affect the walkability of the built environment. Pedestrian safety is fundamental to be taken into consideration. A well-designed street should keep pedestrians safe from vehicular traffic by providing proper sidewalks, curbs, signals and markings [24]. Universal design principles should be incorporated for creating an inclusive environment which is barrier-free and accessible by all to cater to the needs of vulnerable groups, including people with disabilities and older adults [25].

Public spaces should be provided with adequate lighting specifically during the night for illumination [26]. Aside from actual safety, pedestrians must be safe from crime or danger. An active street life enables a safer walkable environment due to the existence of people and "plenty of eyes on the street" for surveillance [27]. Crime prevention through environmental design strategies should be incorporated in the design of public spaces to 
enhance visibility for natural surveillance and deter crime by enhancing the perceived risk of detection [28].

Another design factor in creating walkable cities is the scale of public spaces that can be enhanced if the human scale is taken into account. Wide motorways full of noise, dust and fumes discourage people to pass. Instead of being used predominately by vehicles, streets are recommended to be designed in a pedestrian-friendly manner. The width of sidewalks should be wide enough for people to walk comfortably and can be wider to facilitate social interaction and other activities $[29,30]$. Trees and vegetation can be added to enhance the microclimate of public spaces [31]. The appropriate use of street furniture, lighting, signage and paving all contribute to the enhancement of a walkable urban environment [32]. A vehicle-free policy has been actively promoted worldwide to convert selected streets through pedestrianisation [33-35]. Pedestrianised streets encourage walking and foster social and cultural activities to take place.

\subsubsection{Density and Walkability}

Gehl noted that higher densities in urban areas lead to revitalization and liveliness of communities, and increase the tendency towards choosing walking over other means of transportation means (car, bus, train, etc.) [36,37]. Density is a key concept in urban design and planning. Referring to the planning proposals of Le Corbusier, such as Ville Contemporaine (Contemporary City) in 1922 and the Plan Voisin in 1925, high density was one of the fundamental principles in creating walkable cities. In Ville Contemporaine, Le Corbusier proposed to erect 24 identical skyscrapers of 60-storeys high, each in a rigid grid pattern, but each skyscraper was erected at wide intervals on a vast open space with merely $5 \%$ site coverage (leaving $95 \%$ of the land left open and unbuilt) [38].

Compared with Le Corbusier's modernist tower typology, Jane Jacobs, in her seminal book, The Death and Life of Great American Cities, advocated a high-density low-rise approach. Using Greenwich Village as an example, the high density of more than 200 dwellings per acre was achieved by having a site coverage of up to $80 \%$ (leaving the remaining approximately $20 \%$ of the land left open and unbuilt) [27]. Therefore, building height itself is not an indication of density. A 10-storey building on $10 \%$ of the site has the same floor area as a single-storey building with $100 \%$ site coverage [39]. The ratio of floor area to land area or 'floor area ratio' is a common measurement of building density but without a direct correlation with population density. The measurement of density as dwellings per acre or dwellings per hectare is also commonly used but depends on the size of dwellings and the size of households [40].

Population density based on census data about residents per hectare does not provide a clear picture of the actual concentration of people in the city. Population density fluctuates throughout the day and can vary quite substantially between working days and weekends. Therefore, no single density measure is useful in understanding walkability [39]. Instead of using density, Jacobs referred to "dense concentration of people" as one of the conditions for urban diversity and intensity because bringing people of different ages, abilities and ethnicities is "needful for flourishing city life" and "a visibly lively public street life" [27].

A dense concentration of people is a necessary condition for urban diversity and intensity but not a sufficient condition by itself. Other factors of having a proper pedestrian network and a mixed use of spaces are crucial for achieving a walkable built environment.

\subsubsection{Street Connectivity and Walkability}

Some studies used observational tools to assess the effect of street connectivity and streetscape characteristics [41,42]. By contrast, other studies used geographic information system (GIS) to measure the impact of the enclosure and human scale on walkability experience [43]. The common finding of these studies is that street connectivity, level of vegetation and leaf area index have significant effects on street walkability.

Connectivity of path network correlates with street patterns. Grid street patterns with equal-sized square or rectangular blocks provide ease of movement for pedestri- 
ans, whereas dead-end streets and cul-de-sacs create very limited connection and access points [44]. Although cul-de-sacs do not allow vehicles to pass through, they can be connected to pedestrian networks if publicly accessible easement or right-of-way exists. Aside from dead-end streets and cul-de-sacs, other potential barriers to pedestrian access include busy motorways, rivers, slopes or other topographic features [45].

The street pattern is associated with block size. When block size becomes smaller, the urban structure becomes finer and better connected with many intersections. Jacobs pointed out that "frequent streets and short blocks are valuable because of the fabric of intricate cross-use that they permit amongst the users of a city neighbourhood" [27]. Short blocks enhance connectivity by offering additional opportunities to turn corners and alternative path choices to walk.

The walkability of the built environment is enhanced if the pedestrian network is connected to public transportation modes. This facilitates people to take public transport, reduces car dependency and increases the pedestrian flow. Moreover, if destinations within walking distance are well connected, then people will be encouraged to walk rather than drive. Jacobs and Pafka used the phrase "pools of use" to refer to the zone accessible by walking at a particular urban location measured by distance or time [27,39].

In addition to street connectivity, the streetscape and its scale also play important roles in encouraging walkability in cities. Some studies used observational tools to assess the effect of streetscape characteristics on walkability [41,42]. The findings of these studies showed that street trees and leaf area index block the sight and mitigate the scale of buildings and wide streets, thereby further enhancing the built environment for pedestrians [46]. Other studies used GIS to measure the effect of the enclosure and human scale on walkability experience [43]. Franck and Stevens showed that the human-scaled neighbourhood plays an important role in promoting the number of interactions in urban spaces and therefore significantly affects the walkability index [47].

\subsubsection{Mixed-Use Development and Walkability}

The influence of dense and mixed-use development on social life and walkability has been well established in the literature [27,36,48]. Gehl showed that small-scale cities with dense and mixed-use urban morphology host a higher number of city events and encourage people to walk further to observe these social events and day-to-day activities [36]. The positive effect of mixed-use development, integration of commercial with residential zoning and physical qualities (urban furniture, sidewalks) on social life and walkability was confirmed [49]. Modernist urban planning encouraged a clear demarcation of zoning for different functions. From the Plan Voisin of Le Corbusier [38], a large part of central Paris was proposed to be demolished under urban renewal and replaced by a group of office skyscrapers surrounded by parkland. The use of vehicles as a means of transportation was promoted by wide motorways, and the city was divided into commercial, residential, cultural and industrial areas.

Jacobs strongly criticised the tabula rasa approach and clear segregation of monofunctional zones of modernist urban planning [27]. Jacobs stressed the importance of mixed uses through detailed observations of everyday urban life. Jacobs noted that "To understand cities, we have to deal outright with combinations or mixtures of uses, not separate uses, as the essential phenomena". In addition, Jacobs distinguished two types of mixed-use diversity, namely, primary and secondary uses. The former bring people to specific places, such as offices, dwellings and factories. A popular restaurant and even a small family café can draw people as primary uses. Secondary uses refer to the enterprises that grow in response to the presence of primary uses, and the primary uses draw in response to a variety of users' needs to serve the people. Regardless of how successful primary and secondary uses are, city diversity is only achieved when different uses are combined and mixed [50].

Apart from having mixed uses in close proximity with one another, the activities to be concentrated within a particular time of the day should be avoided. An appropriate 
functional mix can attract people to go outdoors on various schedules. When people walk on the streets and use public spaces at different times of the day, the city is much safer and more enjoyable [51]. The 24-h city concept has been developed in some areas to bring a wide range of groups back to city centres after office hours through mixed-use programmes [52].

In the past, traditional cities were compact with narrow streets, and pre-occupied with human activity. Today, many of these cities are adapted to accommodate the car with wider roads, more car parking spaces, and lower population densities, with space between urban buildings reserved for automotive use. Lower population densities meant urban sprawl with longer distances between places. This process led to changes in urban form and street connectivity that offered little opportunity for people without a car, made older transport unattractive or impractical, created further car dependency, and finally resulted in reduced level of walkability. Moreover, falling energy prices and rising car ownership have further transformed cities, allowing the increased physical separation of activities and the progressive spread of urban hinterland at lower densities. The next section provides an overview of the key urban design elements that made Iranian traditional cites into walkable cities.

\subsection{Key Urban Design Elements in Iranian Traditional Cities Contributing to Walkability}

Habibi stated that urban design and planning can be divided into pre-Islamic (9 BC-7 AD) and post-Islamic (7 AD-today) periods in Iran [53]. Urban design features and elements belonging to the pre-Islamic period have been mainly collected through archaeology. According to the archaeological evidence, a diverse range of urban forms, patterns and morphologies were identified due to the presence of different emperors ruling the country in pre-Islamic Iran [53]. After the Arabic invasion to Iran, new types of urban patterns and morphologies were added to Iranian cities, which were mainly inspired by the pre-Islamic concepts in city planning. These new urban forms and urban design elements made the Iranian cities unique and distinctive from other traditional cities in the world. In this study, traditional Iranian cities refer to the cities that have been formed and developed within the post-Islamic period. In this section, a brief overview of the prevailing urban morphology in traditional Iranian cities will be provided and each urban design element that contributes to walkability will be discussed.

The number of people per house was higher in the past than today in Iranian traditional cities, as people tended to have more children and all family members used to live together, even after marriage. This case is in contrast to today's societies where people live in dispersed suburbs and mainly rely on their vehicles to reach their destinations. The car dependency is known as the main source of lack of vitality, public social life and walkability in today's cities [27]. The presence of bazaars in traditional Iranian cities and their proximity to the mosque (the core and heart of the cities), mahalleh (residential quarters), madrasah (school), maidan (square) and hammam (public bath) through connected and permeable alleyways created an urban life in which all of the neighbourhood's daily needs could be responded within walking distance. Taking the heritage part of Shiraz city (a city located in the central part of Iran) (also known as old Shiraz) as an example, all the uses and requirements of the people's everyday life were located within a $1 \mathrm{~km}$ radius from the centre of the city (which was the community mosque). In the old city of Shiraz, people often walked from their homes to communal and public spaces, and the use of cars was only limited to travelling to the outskirts of the cities. Aside from walking distances, the quality of sidewalks and the provision of thermally comfortable outdoor spaces through shaded narrow alleyways were other factors that encouraged people to walk in the city.

Iranian traditional cities were formed organically with respect to the background climatic conditions and therefore considered as human-scaled built environments. The examples of such spaces are the alleyways in the old city of Yazd, Nasir al-Mulk Mosque in Shiraz and Qeysarriyeh Bazaar in Isfahan (Figure 1). 


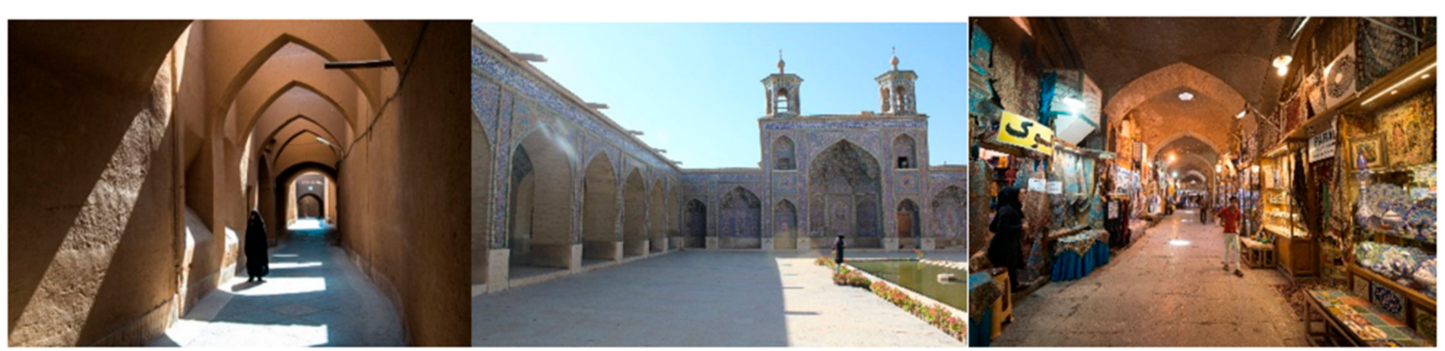

(a)

(b)

(c)

Figure 1. Examples of human-scaled design in shaded narrow alleyways in old city of Yazd (a), Nasir al-Mulk Mosque in Shiraz (b) and Qeysarriyeh Bazaar in Isfahan (c). Source: Flickr.com. (accessed on 11 August 2016).

In Iranian traditional cities, houses were limited to one-storey height, and the narrowshaded alleyways provided friendly and comfortable routes for a day-to-day journey of urban dwellers. A human-scaled design, narrow alleyways and connected public spaces (with bazaar and mosque in the central axis) enabled people to greatly observe the public spaces, details, shops and all activities from a close distance.

In Iranian traditional cities, public space played an important role in creating walkable neighbourhoods. The public spaces were pleasurable to inhabit and practical enough to use for day-to-day life. Therefore, public spaces greatly contributed to an increased level of walkability and promoted a sense of identity in these cities. The number of the public spaces in a neighbourhood, the level of their accessibility and the quality of public space were the main factors in encouraging people to walk from their homes to the urban areas or neighbourhood centres.

In the past, public spaces were mainly used for market purposes and social, religious or political events. These spaces were also known as the main place for communicating and interacting with other urban dwellers and trading, and were regarded as the heart of the community [54]. Today, these functions somehow have been replaced by privatised public realms designed and developed by certain agencies who do not often consider the neighbourhood's unique contextual features. This case is the main reason why people are less willing to walk from their homes to the neighbourhood centres or the other public spaces in their communities.

In traditional Iranian cities, three main pillars form the basis of urban life, namely, religion (mosque), trade (bazaar) and family (house) [54-56]. These pillars were formed after Arab's invasion to Iran and followed by a transformation, which was made to address the Islamic belief systems and theories in urban planning.

One of the most significant components of the religion pillar was the community mosque, which was indeed a replacement for Zoroastrian fire temples [56]. In Iranian traditional cities, the overall urban morphology and diverse range of public spaces increased the interactions amongst people with different socio-economic backgrounds. In addition to their primary uses, these public spaces were able to act as third places. Oldenburg and Brissett described the third place as a place of refuge other than home or workplace, where people can relax, commune and interact [57]. A third place satisfies social needs where one can meet friends, colleagues, neighbours and even strangers.

As mentioned, in traditional Iranian cities, three main pillars form the basis of urban life, namely, religion (mosques), trade (bazaars) and family (houses and residential quarters). Therefore, in the next section of this study, we will provide an overview of each of these urban design elements and discuss how these pillars contributed to walkable neighbourhoods.

\subsubsection{Mosques}

The most important public space in Iranian traditional cities is a mosque. Mosques did not only provide worship places for people but also catered for society's need for social life. Mosques were often integrated into central marketplaces (bazaars). This integration 
increased the vital role of the mosque towards creating a public realm that worked well with the daily commercial activities in the city.

As the main communal and public spaces of the community, community mosques were located in a central position in the city [58] and linked to other main public spaces in the city (e.g., bazaar, residential quarters [mahalleh], square [maidan, similar to Roman Forum], hammam [public bath] and madreseh [school]). Each mahalleh had their own mosque in the central location.

The community mosque was also located next to the governmental palace and bazaar and therefore provided a high level of accessibility and connectivity from one function to another. As a result, the community mosques were also known as one of the most important gatherings and interaction spaces, where people could discuss various social, economic and political issues, regardless of their socio-economic background. In addition, mosques, which were attached to madresehs (schools), had a dual function serving some flexible spaces as a school and functioning as educational hubs for learners. Until the beginning of the 20th century, mosques and schools had mostly been an integrated space with integrated functions. A variety of uses near the mosque and the physical and visual connectivity amongst them promoted walkability in traditional Iranian cities. Therefore, people were highly encouraged to take part in social life and walk through the interconnected mosque, bazaar and madrasah. In Shiraz, for example, the only government-built mosque was Vakil Mosque, which is located next to the Vakil bazaar (Figure 2). A bazarcheh and the madreseh can be found next to each local mosque, serving as public amenities and providing high-quality public spaces which in turn led to high walkability.
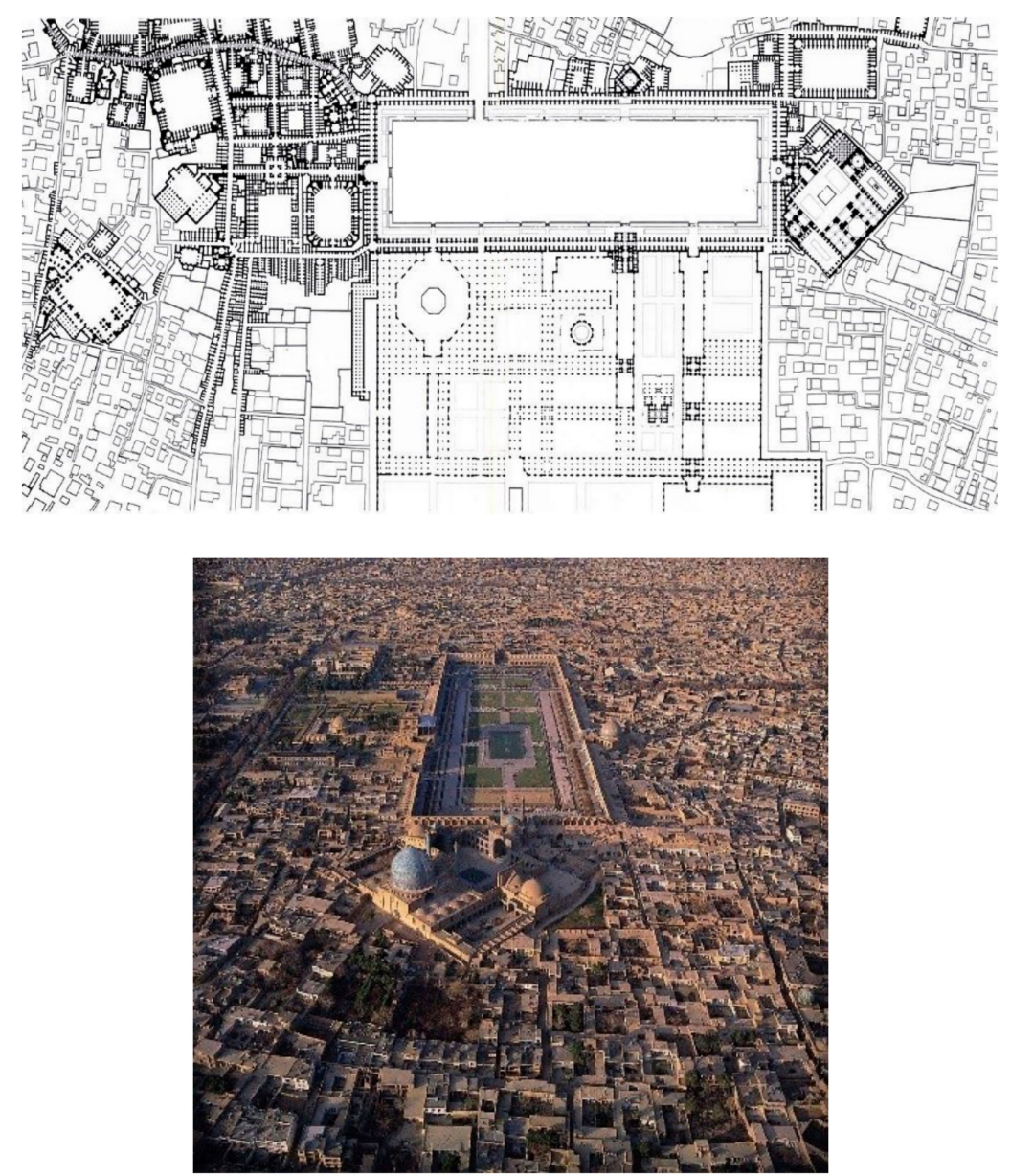

(a)

Figure 2. Cont. 


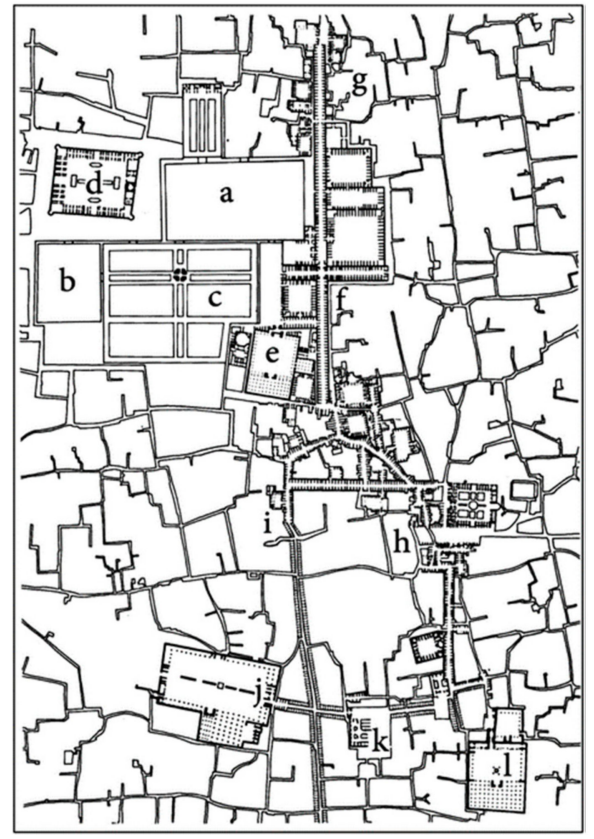

(b)

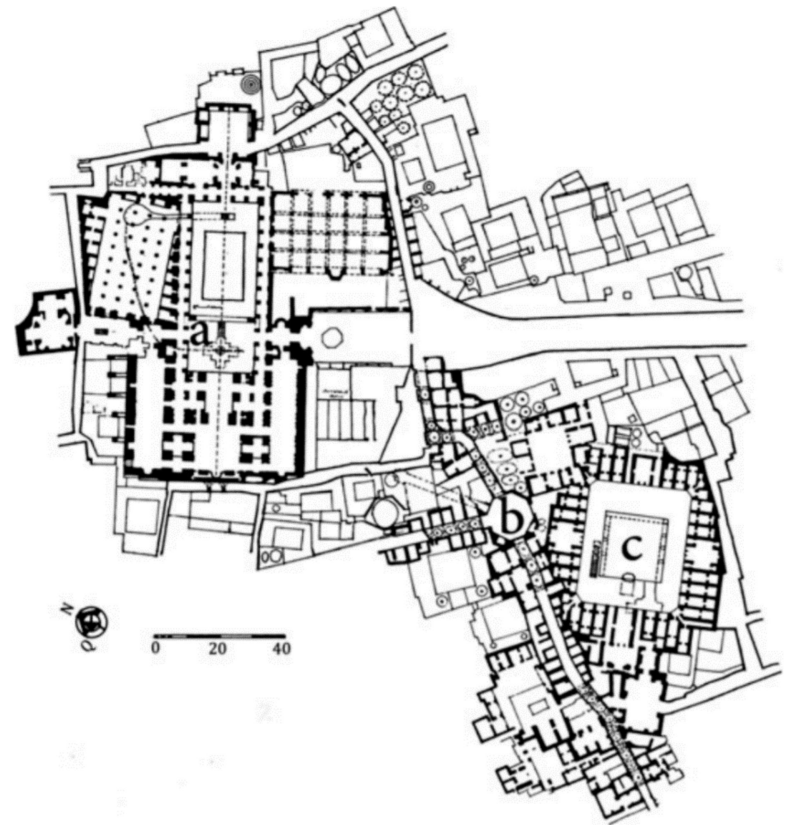

(c)

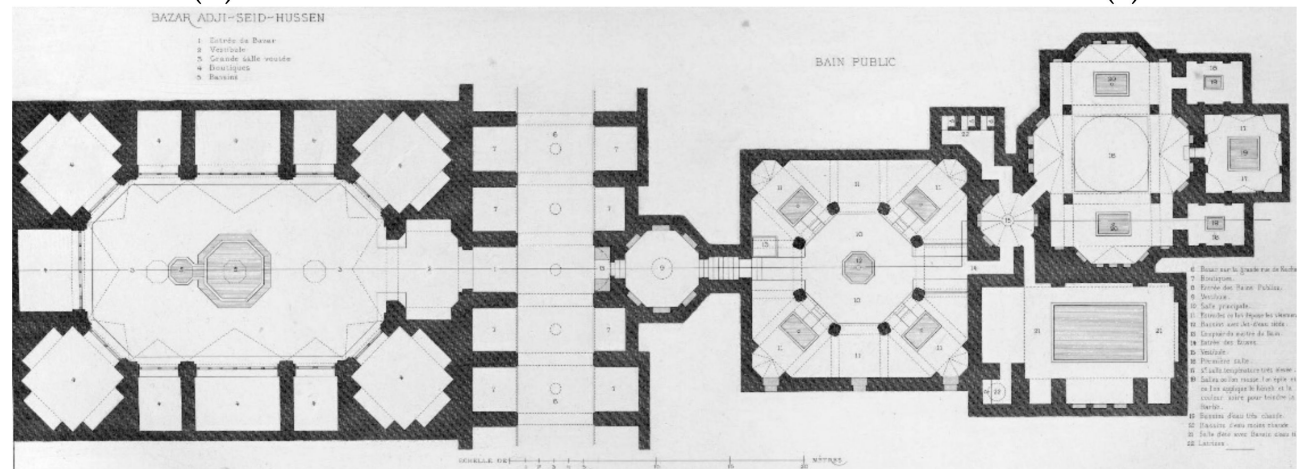

(d)

Figure 2. (a) Isfahan. Masjid-i Hakim linked with the main bazaar plan (top); Isometric view (bottom). Source: (Ministry of Culture and Arts of Iran, 1976); (b) Shiraz. The bazaar complex, nineteenth century: a Artillery square. b Training square. c Bagh-i Nazar (Nazar garden). d Karim khani citadel. e Masjid-i Vakil. f Bazaar lanes connected with caravanserais. g Bazaar-i Now. h Bazaar-i Hajji. i Bazaar-i Morg. j Masjid-i Now (new congregational mosque). k Seyyed Amir Ahmad b. Musa (today's famous Shah-i Cheragh) and Seyyed Amir Mohammad shrines. 1 Masjid-i Jami-yi Atiq/old congregational mosque (from Tavassoli and Bonyadi, 1993). Source: (Tavassoli, 2016); (c) Yazd. The historic inner core; plan is showing integration of the old city centre with the surrounding housing areas: a Masjid-i Jami. b Bazaar/Chahar su. c Madrasah. d Madrasah and Tomb of Seyyed-i Rokn al-Din (a prominent public figure). e Maydan (named after Seyyed-i Rokn al-Din). f Hammam (demolished). g Traces of Mozaffarid wall, thirteenth century (from Tavassoli, 1986). Source: (Tavassoli, 2016); (d). Haji Seid Hussein and bathhouse Kashan. Source: (Coste, 2011).

\subsubsection{Bazaars}

The second urban design element that contributed to walkable communities in Iranian traditional cities was the bazaar and its physical and structural integration with mosques. The bazaar was also known as "the second heart of the city" in traditional cities of Iran [59]. Additionally, the bazaar was the most significant spatial axis in the social life of cities [60] and was first introduced by Medes and Achaemenids during the ancient Persian Empire [54]. In fact, bazaars and mosques are known as the two major lungs and the backbone of Iranian traditional cities.

Bazaars had mainly a linear form [55] and were situated in the central part of the city. Each residential quarter had their own minibazaar, known as bazarcheh. Bazarches were connected to the main mosque from one side and to mahallehs (residential quarters) 
from the other side. Moreover, they were the main destination for all the major pedestrian pathways [56,61]. Bazaars had commercial and manufacturing uses and also fulfilled the needs of people to interact and discuss the political, social and economic status of their cities [55]. Bazaars played a key role in connecting the residents of the city with major public spaces and outsiders [62].

Although the alleyways and houses were built for protection, the attached mosques and bazaars enabled a further level of walkability by providing a high level of various activity patterns, increased active frontages (shops) and the creation of series of open public realms in between. In this important urban element of Iranian traditional cities, the nature of the bazaar as the heart and the core of the city with diverse types of activities and the provision of thermally comfortable spaces resulted in the highest level of pedestrian walkability. The shaded storefronts accommodated gathering spaces in bazaars and narrow covered passageways with low sky view factors contributed to better thermal comfort for pedestrians and therefore increased level of walkability (Figure 3). As the main social and pedestrian network of the city, the bazaar played a vital role for hosting various public gatherings in the enhancement of city's liveability and walkability.

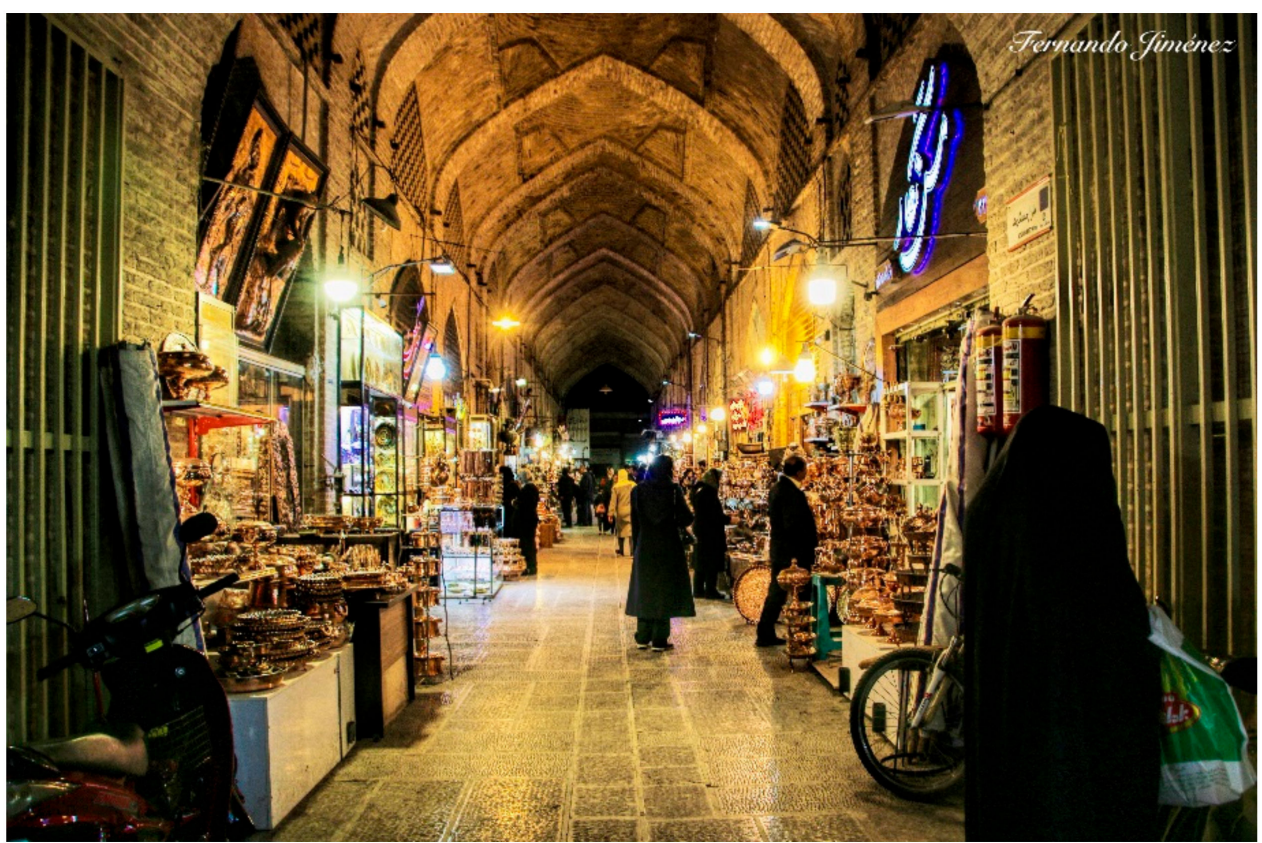

Figure 3. Isfahan bazaar, shopfronts and covered passageways. Source: Flickr.com (accessed on 27 February 2019).

\subsubsection{Residential Quarters (Mahalleh) and Alleyways}

Mahallehs in traditional Iranian cities refer to "the residential quarters that are scattered in the city" and are known as one of the main elements of social life in traditional Iranian urban planning [63]. Although the residents of each mahalleh had similar ethnicity, cultural and religious backgrounds $[56,61]$, the mahallehs were not segregated by any physical barriers, such as walls [55].

Each mahalleh had their local mosque, hammam (bath), bazarcheh (minibazaar) and other civic amenities, which made them walkable and accessible to the residents [60]. Figure 4 shows the skyline of a residential quarter (mahalleh), situated in the old city of Yazd. Figure 4 also shows that this residential quarter is characterised by compact urban form and shaded, covered alleyways. 


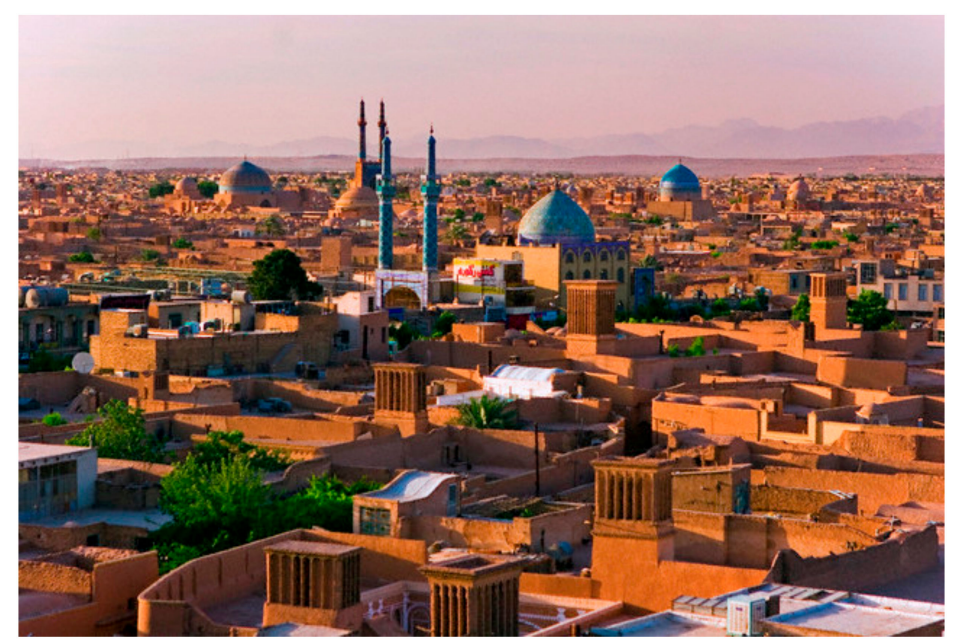

Figure 4. A residential neighbourhood in Yazd, a typical compact, shaded structure. Source: Flickr.com (accessed on 15 June 2017).

The connection between the mahallehs (residential quarters) and bazaars (commercial quarters) was through a series of narrowed and covered alleyways, sometimes blocked by cul-de-sacs from one side [61]. These alleyways were covered, mainly because of the security and protection against sun, wind and occasional rain, and for providing thermally comfortable urban spaces in hot-arid climates (the dominant climate in most of the traditional Iranian cities located in the central parts of Iran). Strategic openings along these narrow and shaded pathways avoided the creation of wind tunnel and reduced the wind speed in winter.

These covered alleyways enabled further protection against the invaders in case of breaking the fortification walls. The human-scale design principle of the alleyways also played an important role in encouraging further walkability in each mahalleh. An example of such an alleyway is shown in the old city of Yazd in Figure 5. In this mahalleh, walkability was also supported by a strong pedestrian circulation network. These pedestrian networks had two main functions. Firstly, they were part of a transportation system in the city and provided access to different functions. Secondly, they acted as neighbourhood spaces by providing safety, continuity and thermal comfort.

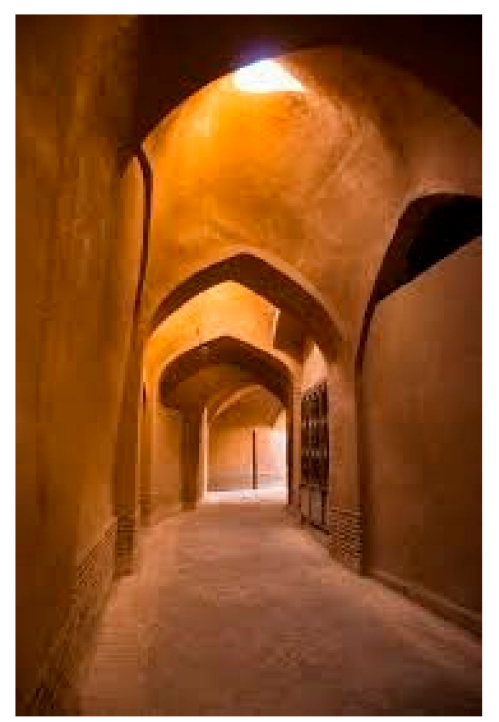

Figure 5. Narrow-shaded alleyways in old city of Yazd. (22/2/2008) Source: Flickr.com (accessed on 22 February 2008). 
The alleyways were narrower within the distances away from the bazaar [64]. These alleyways were organically shaped, but their hierarchical structure is somehow differentiated from the private, public, semi-public and semi-private urban zones. For example, the parts near the cul-de-sacs were the gathering zones for the residents of neighbouring houses and were mainly used by housewives and as a children's playground by the household's children.

The housing typology in all the mahallehs was introverted. These houses were attached by walls, indicating a strong emphasis on the segregation between indoor and outdoor (public and private zones) in traditional Iranian houses [65]. Therefore, the role of public spaces, such as mosques, bazaars, schools and baths, was critical in creating a vibrant social life and promoting people to walk in their mahallehs.

The building typologies of houses were mainly introverted, and the entrance to houses was the only interface between inside and outside domains (public and private zones).

Pîrneshîns can be observed next to the entrance doors of these houses, which were created next to the entrances of each house and were commonly known as communal spaces for neighbours to gather and speak to each other'. Pîrneshîn was a place for sitting, resting space for older adults and accommodating people who were tired of carrying heavy loads. This amenity automatically resulted in further social interactions and sense of community amongst people in traditional neighbourhoods, as it promoted face-to-face communication amongst neighbours.

In addition to Pirneshins, most of the houses had fixed seating places in front of their doors, mainly for utilisation of older adults of the household or the community. This simple urban furniture somehow became a gathering space for older adults to get together and socialise with the neighbours passing by. This amenity also increased the level of passive surveillance in the neighbourhood which then led to secure urban spaces. These seating places are comparable with porches in Western architecture, where the residents perform their daily routine in a semi-private, semi-public zone. This notion is in line with the findings of Gehl's study on the influence of front yards, informal seating spaces and urban furniture on encouraging walkability in a city [66].

Each mahalleh had its own centre (neighbourhood centre), which was formed around a small public square (maidan). The purpose of mahalleh centre was to provide civic amenities and urban infrastructure, enhancing the sense of community and identity amongst each mahallehs' resident. Although each mahalleh can cater for the needs of its residents, the connection between the mahallehs with public spaces was through the alleyways which enabled people to have easy access in different parts of their cities and walk to their destinations.

The level of walkability and social life in each mahalleh relied on the functionality and attractiveness of the mahalleh centre and its nearby elements, such as community mosque, bazarcheh and schools. Therefore, allocating a bazarcheh and a public bath near each mahalleh centre was mainly focused.

Traditional Iranian mahallehs consisted of a diverse range of uses located in proximity to each other and within walking distances. For example, in the old cities of Shiraz and Isfahan, we can observe how the residential, commercial, cultural and institutional uses are positioned next to each other and adjacent to the mahalleh centre. These uses provided the main attraction for the mahallehs' residents to travel to these destinations, as they did not only address the daily needs of residents but also provided vibrant public spaces next to each other. Therefore, the mahalleh centre was considered a social hub that invited people for further interaction. The strategic positioning of these public spaces next to the mahalleh centre and their linkage with residential quarters via permeable and accessible alleyways were other factors in forming walkable neighbourhoods in traditional Iranian cities.

Notably, the design of the neighbourhood also considered the needs of people with special needs (disabled, older adults, children). Therefore, this design provided a variety of choices available in urban spaces for people with different needs and socio-economic backgrounds. 


\section{Discussion and Conclusions}

This study first examined the influence of urban design and unique public spaces in Iranian traditional cities on walkability by focusing on how density, mixed-use development and connected pedestrian networks brought the organic but thoughtful urban design in these cities (using Frank Lawrence's theory of "Objectively Measured Urban Form" (density, connectivity and accessibility, and mixed-use development) as the basis of discussion.

As the core, commercial hub and backbone of Iranian traditional cities, bazaars acted as the linkage between different urban design elements in the city and created strong connections amongst residential quarters, public squares, schools, public baths and mosques. Bazaars were also the main gathering spaces in the cities and mimicked the plazas in the Middle Ages of Europe. The key role of bazaars as the main public domain was another factor in increasing the walkability in cities.

Another important feature of Iranian traditional cities was their integrity in the way they connect people to key public spaces. The strong linkage between public and private spaces and functioning as a whole created and facilitated interactions amongst members of the communities with different socio-economic backgrounds. This strong pedestrian and street network in addition to the unity and cohesion of diverse land uses created a highly walkable urban environment in these cities. The positioning of different land uses next to each other (commercial, religious, housing, recreational and roads) and high-density urban development was another governing factor in creating a city where people prefer to travel on foot.

Mixed-use, high-density urban development and connected alleyways have made each residential quarter a self-sufficient and walkable urban area. In these residential quarters, people had a high level of accessibility to their neighbours' houses and the local public spaces in their neighbourhoods. All of these residential quarters had certain public spaces in common, such as mosque, bazaars, alleyways, public squares and baths. These urban design elements and their proximity next to each other were the main reasons that people prefer to walk to their destinations. The hierarchical, thermally comfortable and safe alleyways in association with seating spaces and other street amenities (urban furniture) for older adults were also another important urban design parameter in creating such walkable neighbourhoods. The connected series of pedestrian and street networks clearly defined the transition from public to private zones. Therefore, the sense of safety and security was increased, and as a result, the design of children's playgrounds and neighbours' gathering places was encouraged. Considering the inherent values of traditional urban forms will be a complement to the modern planning and design techniques and will facilitate the creation of walkable neighbourhoods.

This study concludes that the Iranian traditional urban spaces and housing typologies highlight bold segregation between private and public spaces. However, the connected public spaces and alleyways created a city where people could prefer walking over any other transportation means. By taking a case study approach, this study showed that bazaars, mosques, residential quarters, alleyways and public squares form the main urban morphology in Iranian traditional cities. Bazaars (commercial use) were mainly situated near the mosques (religious use) and were surrounded by a series of alleyways that connected courtyard houses located in different residential quarters. The high level of housing density around the bazaar and mosque, and the inherent mixed-use development were the main contributing factors in promoting walkability in the Iranian traditional cities.

Author Contributions: Conceptualization, E.J. and K.A.; Literature review, E.J., K.A., and H.W.C.; writing-original draft preparation, E.J., K.A., and H.W.C.; writing—review, analysis, and editing, M.S., B.H., and A.S.; supervision, E.J., M.S., B.H., and A.S.; project administration, M.S., and B.H. All authors have read and agreed to the published version of the manuscript.

Funding: This research received no external funding.

Institutional Review Board Statement: Not applicable. 
Informed Consent Statement: Not applicable.

Data Availability Statement: Publicly available datasets were analyzed in this study.

Conflicts of Interest: The authors declare no conflict of interest.

\section{References}

1. Forsyth, A. What is a walkable place? The walkability debate in urban design. Urban Des. Int. 2015, 20, 274-292. [CrossRef]

2. Saelens, B.E.; Sallis, J.F.; Frank, L.D. Environmental correlates of walking and cycling: Findings from the transportation, urban design, and planning literatures. Ann. Behav. Med. 2003, 25, 80-91. [CrossRef] [PubMed]

3. Dannenberg, A.L.; Bauer, D.R.; Bland, A.D.; Hobson, S.E.; Rose, K. From Health Destruction to Health Promotion: Conversion of a Worksite Smoking Shelter. Am. J. Prev. Med. 2007, 32, 86. [CrossRef] [PubMed]

4. Boarnet, M.G.; Greenwald, M.; McMillan, T.E. Walking, urban design, and health: Toward a cost-benefit analysis framework. J. Plan. Educ. Res. 2008, 27, 341-358. [CrossRef]

5. Maizlish, N.; Linesch, N.J.; Woodcock, J. Health and greenhouse gas mitigation benefits of ambitious expansion of cycling, walking, and transit in California. J. Transp. Health 2017, 6, 490-500. [CrossRef]

6. Pérez, K.; Olabarria, M.; Rojas-Rueda, D.; Santamariña-Rubio, E.; Borrell, C.; Nieuwenhuijsen, M. The health and economic benefits of active transport policies in Barcelona. J. Transp. Health 2017, 4, 316-324. [CrossRef]

7. Cerin, E.; on behalf of the Council on Environment and Physical Activity (CEPA) Older Adults working group; Nathan, A.; Van Cauwenberg, J.; Barnett, D.W.; Barnett, A. The neighbourhood physical environment and active travel in older adults: A systematic review and meta-analysis. Int. J. Behav. Nutr. Phys. Act. 2017, 14, 1-23. [CrossRef]

8. Ding, D.; Sallis, J.F.; Kerr, J.; Lee, S.; Rosenberg, D.E. Neighborhood environment and physical activity among youth: A review. Am. J. Prev. Med. 2011, 41, 442-455. [CrossRef]

9. Brenlea, F.; Wagner, D.; Alberto, N.A.; Christine, F. Evidence synthesis A systematized literature review on the associations between neighbourhood built characteristics and walking among Canadian adults, Health promotion and chronic disease prevention in Canada. Res. Policy Pract. 2019, 39, 1.

10. Smith, M.; Hosking, J.; Woodward, A.K.; Witten, K.; MacMillan, A.; Field, A.; Mackie, H. Systematic literature review of built en-vironment effects on physical activity and active transport-an update and new findings on health equity. Int. J. Behav. Nutr. Phys. Act. 2017, 14, 158. [CrossRef]

11. Van Cauwenberg, J.; the Council on Environment and Physical Activity (CEPA)-Older Adults Working Group; Nathan, A.; Barnett, A.; Barnett, D.W.; Cerin, E. Relationships Between Neighbourhood Physical Environmental Attributes and Older Adults' Leisure-Time Physical Activity: A Systematic Review and Meta-Analysis. Sports Med. 2018, 48, 1635-1660. [CrossRef]

12. Lee, I.-M.; Shiroma, E.J.; Lobelo, F.; Puska, P.; Blair, S.N.; Katzmarzyk, P. Effect of physical inactivity on major non-communicable diseases worldwide: An analysis of burden of disease and life expectancy. Lancet 2012, 380, 219-229. [CrossRef]

13. Saelens, B.E.; Sallis, J.F.; Black, J.B.; Chen, D. Neighborhood-Based Differences in Physical Activity: An Environment Scale Evaluation. Am. J. Public Health 2003, 93, 1552-1558. [CrossRef]

14. Dygryn, J.; Mitas, J.; Stelzer, J. The Influence of Built Environment on Walkability Using Geographic Information System. J. Hum. Kinet. 2010, 24, 93-99. [CrossRef]

15. Ewing, R.; Schmid, T.; Killingsworth, R.; Zlot, A.; Raudenbush, S. Relationship between urban sprawl and physical activity, obesity, and morbidity. Am. J. Health Promot. 2003, 18, 47-57. [CrossRef]

16. Frank, L.D.; Andresen, M.A.; Schmid, T.L. Obesity relationships with community design, physical activity, and time spent in cars. Am. J. Prev. Med. 2004, 27, 87-96. [CrossRef]

17. Dannenberg, A.L.; Jackson, R.J.; Frumkin, H.; Schieber, R.A.; Pratt, M.; Kochtitzky, C.; Tilson, H.H. The Impact of Community Design and Land-Use Choices on Public Health: A Scientific Research Agenda. Am. J. Public Health 2003, 93, 1500-1508. [CrossRef]

18. Lavizzo-Mourey, R.; McGinnis, J.M. Making the Case for Active Living Communities. Am. J. Public Health 2003, 93, 1386-1388. [CrossRef]

19. Frank, L.; Engelke, P.; Schmid, T. Health and Community Design: The Impact of the Built Environment on Physical Activity; Island Press: Washington, DC, USA, 2003.

20. Bauman, A.; Armstrong, T.; Davies, J.; Owen, N.; Brown, W.; Bellew, B.; Vita, P. Trends in physical activity participation and the impact of integrated campaigns among Australian adults, 1997-1999. Aust. N. Z. J. Public Health 2003, 27, 76-79. [CrossRef]

21. Frank, L.D.; Schmid, T.L.; Sallis, J.F.; Chapman, J.; Saelens, B.E. Linking objectively measured physical activity with objectively measured urban form: Findings from SMARTRAQ. Am. J. Prev. Med. 2005, 28, 117-125. [CrossRef]

22. Francis, J.; Giles-Corti, B.; Wood, L.; Knuiman, M. Creating sense of community: The role of public space. J. Environ. Psychol. 2012, 32, 401-409. [CrossRef]

23. Zhang, W.; Lawson, G. Meeting and greeting: Activities in public outdoor spaces outside high-density urban residential communities. Urban Des. Int. 2009, 14, 207-214. [CrossRef]

24. Jacobs, A.B. Great Streets Cambridge; MIT Press: Cambridge, MA, USA, 1993.

25. Steinfeld, E. Universal Design: Creating Inclusive Environments; John Wiley \& Sons: Hoboken, NJ, USA, 2012.

26. Davoudian, N. Urban Lighting for People: Evidence-Based Lighting Design for the Built Environment; RIBA Publishing: London, UK, 2019. 
27. Row, A.T.; Jacobs, J. The Death and Life of Great American Cities. Yale Law J. 1962, 71, 1597. [CrossRef]

28. Crowe, T.D. Crime Prevention through Environmental Design; Elsevier: Amsterdam, The Netherlands, 2013.

29. Emery, J.; Crump, C.; Bors, P. Reliability and Validity of Two Instruments Designed to Assess the Walking and Bicycling Suitability of Sidewalks and Roads. Am. J. Health Promot. 2003, 18, 38-46. [CrossRef]

30. Gassaway, A.R. The adequacy of walkways for pedestrian movement along public roadways in the suburbs of an American city. Transp. Res. Part A Policy Pract. 1992, 26, 361-379. [CrossRef]

31. Erell, E. Urban Microclimate: Designing the Spaces between Buildings London; Earthscan: Washington, DC, USA, 2011.

32. Oc, T.; Tiesdell, S. Urban. Design: Ornament and Decoration; Routledge: London, UK, 2007.

33. Nieuwenhuijsen, M.J.; Khreis, H. Car free cities: Pathway to healthy urban living. Environ. Int. 2016, 94, 251-262. [CrossRef]

34. Gehl, J. A changing Street Life in a Changing Society. Places 1989, 6, 8-17.

35. Vernez-Moudon, A. Public Streets for Public Use; VanNostrand Reinhold: New York, NY, USA, 1987.

36. Gehl, J. Life Between Buildings: Using Public Space; Island Press: Washington, DC, USA, 2011.

37. Gehl, J.; Gemz, L. Public Spaces-Public Life; Arkitektens forlag: Aarhus, Denmark, 2004.

38. Le Corbusier, The City of Tomorrow and Its Planning; John Rodher: London, UK, 1929.

39. Dovey, K.; Pafka, E. What is walkability? The urban DMA. Urban Stud. 2019, 57, 93-108. [CrossRef]

40. Pont, M.B.; Haupt, P. Spacematrix: Space, Density and Urban Form; NAI: Rotterdam, The Netherlands, 2010.

41. Ewing, R.; Handy, S. Measuring the Unmeasurable: Urban Design Qualities Related to Walkability. J. Urban Des. 2009, 14, 65-84. [CrossRef]

42. Purciel, M.; Marrone, E. Observational Validation of Urban Design Measures for New York City: Field Manual; Robert Wood Johnson Foundation: Princeton, NJ, USA, 2006.

43. Ewing, R.; Handy, S.; Brownson, R.C.; Clemente, O.; Winston, E. Identifying and Measuring Urban Design Qualities Related to Walkability. J. Phys. Act. Health 2006, 3, S223-S240. [CrossRef]

44. Southworth, M.; Owens, P.M. The Evolving Metropolis: Studies of Community, Neighbourhood and Street Form at the Urban Edge. J. Am. Plan. Assoc. 1993, 59, 271-287. [CrossRef]

45. Southworth, M. Designing the Walkable City. J. Urban Plan. Dev. 2005, 131, 246-257. [CrossRef]

46. Arnold, H. Trees in Urban Design; Van Nostrand Reinhold: New York, NY, USA, 1993.

47. Franck, K.; Stevens, Q. Loose Space: Possibility and Diversity in Urban Life; Routledge: Vienna, Austria, 2006.

48. Kashef, M. Sense of Community and Residential Space: Contextualizing New Urbanism within a Broader Theoretical Framework. ArchNet-IJAR 2009, 3. [CrossRef]

49. Mehta, V. The Street: A Quintessential Social Public Space; Routledge: Vienna, Austria, 2013.

50. Montgomery, J. Making a city: Urbanity, vitality and urban design. J. Urban Des. 1998, 3, 93-116. [CrossRef]

51. Fuller, M. An Analysis of Jane Jacobs's The Death and Life of Great American Cities; Routledge: London, UK, 2017.

52. Heath, T. The Twenty-four Hour City Concept-A Review of Initiatives in British Cities. J. Urban Des. 2007, 2, 193-204. [CrossRef]

53. Habibi, S. Azshar ta shahr: Tahlili tarikhi az mafhume shahr va simaye kalbodie an, tafakor va tasvor. In From Shar to City: A Historical Analysis of City and Its Physical Image; Tafakor Va Tasvor: Tehran, Iran, 2009.

54. Clark, T.A. A Better Place to Live: Reshaping the American Suburb; Urban Studies: New York, NY, USA, 1999.

55. Clark, B.D.; Costello, V. The Urban System and Social Patterns in Iranian Cities. Trans. Inst. Br. Geogr. 1973, 99. [CrossRef]

56. Kheirabadi, M. Iranian Cities: Formation and Development; Austin University: Austin, TX, USA, 1991.

57. Oldenburg, R.; Brissett, D. The third place. Qual. Sociol. 1982, 5, 265-284. [CrossRef]

58. Raymond, A. Islamic city, Arab city: Orientalist myths and recent views. Br. J. Middle East. Stud. 1994, 21, 3-18. [CrossRef]

59. Keshavarzian, A. Bazaar and State in Iran: The Politics of the Tehran Marketplace; Cambridge University Press: Cambridge, UK, 2007.

60. Barimani, F.; Barabadi, S. Bafte Ghadime Shahrha Jelveye Farhange Madi va Maenavie Shahrhaye Eslami: Morede Bafte Ghadime Shahre Khaf; Joghrafia Va Tose: Tehran, Iran, 2009.

61. Ehlers, E.; Floor, W. Urban change in Iran, 1920-1941. Iran. Stud. 1993, 26, 251-275. [CrossRef]

62. Karimi, K. The Spatial Logic of Organic Cities in Iran and the United Kingdom. Int. Space Syntax. Symp. 1997, 1, 1-17.

63. Khaghani, S. Islamic Architecture in Iran: Poststructural Theory and the Architectural History of Iranian Mosques; Bloomsbury Publishing: London, UK, 2012.

64. Shieh, E. Ba Shahr va Mantaghe dar Iran [City and Region in Iran]; University of Science and Technology: Tehran, Iran, 2009.

65. Rapoport, A. The nature of the courtyard house: A conceptual analysis. Tradit. Dwell. Settl. Rev. 2007, 57-72.

66. Gehl, J.; Kaefer, L.J.; Reigstad, S. Close encounters with buildings. Urban Des. Int. 2006, 11, 29-47. [CrossRef] 